PressAcademia Procedia

\title{
EQUITY RETURN ANOMALIES IN TURKISH MARKETS
}

\author{
DOI: 10.17261/Pressacademia.2020.1369 \\ PAP- V.12-2020(33)-p.108-109
}

Yigit Atilgan ${ }^{1}$, A. Doruk Gunaydın ${ }^{2}$

${ }^{1}$ Sabanci University, Sabanci Business School, Istanbul, Turkey. yatilgan@sabanciuniv.edu, ORCID: 0000-0003-3818-3300

${ }^{2}$ Sabanci University, Sabanci Business School, Istanbul, Turkey. dorukgunaydin@sabanciuniv.edu, ORCID: 0000-0001-5235-6664

To cite this document

Atilgan Y., Gunaydin A.D., (2020). Equity return anomalies in Turkish markets. PressAcademia Procedia (PAP), V.12, p.108-109.

Permanent link to this document: http://doi.org/10.17261/Pressacademia.2020.1369

Copyright: Published by PressAcademia and limited licensed re-use rights only.

\section{ABSTRACT}

Purpose- The purpose of this study is to investigate the predictive power of various anomalies in the cross-section of equity returns in Borsa Istanbul.

Methodology- Covering a sample period between 1988 and 2018, this study implements univariate portfolio analyses. Specifically, each month, stocks are sorted into quintile portfolios based on one anomaly at a time. Next, the one-month-ahead equal- and value-weighted portfolio returns are calculated for each quintile to test whether the return spread between the extreme anomaly portfolios is economically and statistically significant.

Findings- The findings using the whole sample document that market beta, firm size, lagged return and lottery demand have a significant and negative relation with future stock returns. In contrast, book-to-market ratio, investment and profitability have a strong positive relation with expected equity returns.

Conclusion- All anomalies that are shown to predict U.S. equity returns are not documented in Turkey. Except for the investment anomaly, the directions of these anomalies are in line with the existing literature in the U.S.

Keywords: Equity returns, Borsa Istanbul, anomalies, emerging markets.

JEL Codes: G10, G11, G12

\section{TÜRKIYE PIYASALARINDA PAY GETIRISI ANOMALILERI}

\section{ÖZET}

Amaç- Bu çalışma, Borsa İstanbul’da işlem gören pay senetleri için, pay senedi anomalilerinin, pay senetlerinin gelecekteki getirileri üzerinde anlamlı bir etkisinin olup olmadığını incelemektedir.

Yöntem- 1988-2018 yılları arasındaki dönemi kapsayan bu çalışmada, tek değişkenli portföy analizi kullanılmıştır. Pay senetleri her ay, söz konusu değişkenlerin büyüklüğüne göre beş portföye ayrılmaktadır. Daha sonra, bu portföylerin hem eşit ağırıklı, hem de piyasa değerine göre ağırlıklandırılmış bir sonraki ayki getirileri hesap edilip, uç portföyler arasındaki getiri farkının ekonomiksel ve istatistiki olarak anlamlı olup olmadı̆̆ı test edilmiştir.

Bulgular- Tüm örnekleme bakıldığında, piyasa betası, şirket büyüklüğü, bir payın geçmiş aydaki getirisi ve piyango özelliği ile beklenen pay senedi getirileri arasında negatif bir ilişki görülürken, öz sermayenin defter değerinin piyasa değerine oranı, şirketin toplam varlıklarındaki büyüme (yatııı) ve karlılık oranı ile beklenen pay getirileri arasında pozitif bir ilişkiye rastlanmıştır. Bu anomalilerin yönü yatırım değişkeni haricinde literatürdeki bulgularla uyum göstermektedir.

Sonuç- ABD'de mevcut olan anomalilerin tamamı Türkiye için çalışmamaktadır. Ayrıca, yatırım anomalisi dışında Borsa İstanbul'da çalışan bu anomalilerin yönleri, ABD'deki mevcut literatürle uyumludur.

Anahtar Kelimeler: Pay senedi getirileri, Borsa Istanbul, anomaliler, gelişen piyasalar. JEL Kodları: G10, G11, G12 


\section{REFERENCES}

Ang, A., Chen, J., \& Xing, Y. (2006). Downside risk. The review of financial studies, 19(4), 1191-1239.

Ang, A., Hodrick, R. J., Xing, Y., \& Zhang, X. (2006). The cross-section of volatility and expected returns. The Journal of Finance, 61(1), 259299.

Atilgan, Y., Bali, T. G., Demirtas, K. O., \& Gunaydin, A. D. (2020). Left-tail momentum: Underreaction to bad news, costly arbitrage and equity returns. Journal of Financial Economics, 135(3), 725-753.

Bali, T. G., Cakici, N., \& Whitelaw, R. F. (2011). Maxing out: Stocks as lotteries and the cross-section of expected returns. Journal of Financial Economics, 99(2), 427-446.

Bali, T. G., Cakici, N., \& Whitelaw, R. F. (2014). Hybrid tail risk and expected stock returns: When does the tail wag the dog?. The Review of Asset Pricing Studies, 4(2), 206-246.

Banz, R. W. (1981). The relationship between return and market value of common stocks. Journal of financial economics, 9(1), 3-18.

Carhart, M. M. (1997). On persistence in mutual fund performance. The Journal of finance, 52(1), 57-82.

Cooper, M. J., Gulen, H., \& Schill, M. J. (2008). Asset growth and the cross-section of stock returns. the Journal of Finance, 63(4), 16091651.

Fama, E. F., \& French, K. R. (1992). The cross-section of expected stock returns. the Journal of Finance, 47(2), 427-465.

Fama, E. F., \& French, K. R. (1993). Common risk factors in the returns on stocks and bonds. Journal of Financial Economics, 33, 3-56.

Frazzini, A., \& Pedersen, L. H. (2014). Betting against beta. Journal of Financial Economics, 111(1), 1-25.

Harvey, C. R., \& Siddique, A. (2000). Conditional skewness in asset pricing tests. The Journal of finance, 55(3), 1263-1295.

Hong, H., \& Sraer, D. A. (2016). Speculative betas. The Journal of Finance, 71(5), 2095-2144.

Jegadeesh, N. (1990). Evidence of predictable behavior of security returns. The Journal of finance, 45(3), 881-898.

Jegadeesh, N., \& Titman, S. (1993). Returns to buying winners and selling losers: Implications for stock market efficiency. The Journal of finance, $48(1), 65-91$.

Karceski, J. (2002). Returns-chasing behavior, mutual funds, and beta's death. Journal of Financial and Quantitative analysis, 37(4), 559-594.

Lehmann, B. N. (1990). Fads, martingales, and market efficiency. The Quarterly Journal of Economics, 105(1), 1-28.

Lintner, J. (1969). The valuation of risk assets and the selection of risky investments in stock portfolios and capital budgets: A reply. The review of economics and statistics, 222-224.

Mossin, J. (1966). Equilibrium in a capital asset market. Econometrica: Journal of the econometric society, 768-783.

Newey, W. K., \& West, K. D. (1986). A simple, positive semi-definite, heteroskedasticity and autocorrelationconsistent covariance matrix (No. t0055). National Bureau of Economic Research.

Novy-Marx, R. (2013). The other side of value: The gross profitability premium. Journal of Financial Economics, 108(1), 1-28.

Sharpe, W. F. (1964). Capital asset prices: A theory of market equilibrium under conditions of risk. The journal of finance, 19(3), 425-442. 